\section{Central American Integration System (SICA)}

The Central American Integration System (SICA) was established in Dec. 1991 and became operational in Feb. 1993. SICA is the successor body to the Organization of Central American States, which was suspended in 1973 after a war between El Salvador and Honduras (which were both member countries). It aims to achieve political, economic, social, cultural and ecological integration in Central America and transform the area into a region of peace, liberty, democracy and development.

Members. Belize, Dominican Republic, El Salvador, Guatemala, Honduras, Nicaragua and Panama.

Activities. The Framework Treaty on Democratic Security in Central America, signed in 1995, seeks to achieve a proper 'balance of forces' in the region, intensify the fight against trafficking of drugs and arms, and reintegrate refugees and displaced persons.

Headquarters: Final Bulevar Cancillería, Distrito El Espino, Ciudad Merliot, Antiguo Cuscatlán, La Libertad, El Salvador.

Website: http://www.sica.int

Email: info@sica.int

Secretary-General: Vinicio Cerezo Arévalo (Guatemala).

\section{Eastern Caribbean Central Bank (ECCB)}

The Eastern Caribbean Central Bank was established in 1983, replacing the East Caribbean Currency Authority (ECCA). Its purpose is to regulate the availability of money and credit; to promote and maintain monetary stability; to promote credit and exchange conditions and a sound financial structure conducive to the balanced growth and development of the economies of the territories of the participating governments; and to actively promote, through means consistent with its other objectives, the economic development of the territories of the participating governments.

Members. Anguilla, Antigua and Barbuda, Dominica, Grenada, Montserrat, St Kitts and Nevis, St Lucia, St Vincent and the Grenadines.

Official language: English.

Headquarters: PO Box 89, Bird Rock, Basseterre,

St Kitts and Nevis.

Website: http://www.eccb-centralbank.org

Email: info@eccb-centralbank.org

Governor: Timothy Antoine (Grenada).

\section{Inter-American Development Bank (IDB)}

The IDB, the oldest and largest regional multilateral development institution, was established in 1959 to help accelerate economic and social development in Latin America and the Caribbean. The Bank's original membership included 19 Latin American and Caribbean countries and the USA. Today, membership totals 48 nations, including non-regional members.

Members. Argentina, Austria, The Bahamas, Barbados, Belgium, Belize, Bolivia, Brazil, Canada, Chile, China, Colombia, Costa Rica,
Croatia, Denmark, Dominican Republic, Ecuador, El Salvador, Finland, France, Germany, Guatemala, Guyana, Haiti, Honduras, Israel, Italy, Jamaica, Japan, South Korea, Mexico, the Netherlands, Nicaragua, Norway, Panama, Paraguay, Peru, Portugal, Slovenia, Spain, Suriname, Sweden, Switzerland, Trinidad and Tobago, UK, USA, Uruguay, Venezuela.

Activities. The Bank's total lending up to 2013 was US\$230bn. for projects with a total cost of over US $\$ 481 \mathrm{bn}$. Its lending increased dramatically from the US\$294m. approved in 1961 to US\$13.8bn. in 2013.

Current lending priorities include poverty reduction and social equity, modernization and integration, and the environment. The Bank has a Fund for Special Operations for lending on concessional terms for projects in countries classified as economically less developed. An additional facility, the Multilateral Investment Fund (MIF), was created in 1992 to help promote and accelerate investment reforms and private-sector development throughout the region.

The Board of Governors is the Bank's highest authority. Governors are usually Ministers of Finance, Presidents of Central Banks or officers of comparable rank. The IDB has country offices in each of its borrowing countries, and in Paris and Tokyo.

Official languages: English, French, Portuguese and Spanish. Headquarters: 1300 New York Ave., NW, Washington, D.C., 20577, USA.

Website: http://www.iadb.org

President: Luis Alberto Moreno (Colombia).

\section{Latin American Economic System (SELA)}

Established in 1975 by the Panama Convention, SELA (Sistema Económico Latinoamericano) promotes co-ordination on economic issues and social development among the countries of Latin America and the Caribbean.

Members. Argentina, The Bahamas, Barbados, Belize, Bolivia, Brazil, Chile, Colombia, Costa Rica, Cuba, Dominican Republic, Ecuador, El Salvador, Grenada, Guatemala, Guyana, Haiti, Honduras, Jamaica, Mexico, Nicaragua, Panama, Paraguay, Peru, Suriname, Trinidad and Tobago, Uruguay, Venezuela.

Official languages: English, French, Portuguese and Spanish. Headquarters: Torre Europa, Pisos 4 y 5, Avenida Francisco de Miranda, Urb. Campo Alegre, Caracas 1060, Venezuela.

Website: http://www.sela.org

Permanent Secretary: Javier Paulinich Velarde (Peru).

\section{Latin American Integration Association (ALADI/LAIA)}

The ALADI was established to promote freer trade among member countries in the region.

Members. (14) Argentina, Bolivia, Brazil, Chile, Colombia, Cuba, Ecuador, Mexico, Panama, Paraguay, Peru, Uruguay and Venezuela.

Observers. (28) Andean Development Corporation (CAF), China, Costa Rica, Dominican Republic, El Salvador, European Commission, Guatemala, Honduras, Ibero-American General 